\title{
The prevention of accidental aspiration or swallowing small instruments during implant treatment
}

\author{
Yong-Seo Kim¹, Jee-Young Kim¹, Yu-Ri Heo ${ }^{2}$, Mee-Kyoung Son ${ }^{2 *}$ \\ ${ }^{1}$ Joyful Dental Clinic, Gwangju, Korea \\ ${ }^{2}$ Department of Prosthodontics, School of Dentistry, Chosun University, Gwangju, Korea
}

\begin{abstract}
The aim for this study was to investigate the risks of patients swallowing small instruments, such as Hexa drivers and healing abutments, during implant placement procedures. Various efforts have been put in place to prevent such accidents and to suggest several effective prevention methods for swallowing-accidents by introducing the prevention efforts that had been put or are waiting to be put. On November 12, 2018, we conducted an online questionnaire survey on 500 dentists, who are currently performing implant surgeries, with the assistance of www.dentphoto.com. In the result, approximately $19.2 \%$ of the respondents experienced the risk of their patients swallowing small instruments during implant placement procedures. A total of $79 \%$ of the respondents had an actual experience of such accidents. Nevertheless, many of the respondents answered that they were not taking even the easiest precautions for such accidents due to cumbersomeness and annoyingness. The risk of patients swallowing small instruments during implant placement procedures can be most effectively prevented by dentists and staff being aware of the risks of such accidents, and paying close attention to every step of the procedures. Many of the preventive measures that have been introduced so far, are found to be very effective for the prevention of such accidents. The newly-introduced efforts are also expected to be so.
\end{abstract}

Key Words: Aspiration, Healing abutment, Hexa driver, Implant, Swallowing

@) This is an open-access article distributed under the terms of the Creative Commons Attribution Non-Commercial License (http://creativecommons.org/licenses/by-nc/4.0) which permits unrestricted noncommercial use, distribution, and reproduction in any medium, provided the original work is properly cited.

\section{서 론}

최근 치과 임플란트 치료는 다양하고 효율적인 수술기구 및 기술 그리고 골 이식재의 개발과 더불어 단일치 결손부터 전악 무치악의 경우에 이르기까지, 다양한 증례를 가진 치아결손의 경우에서 보편적으로 사용하는 치료기술로 발전하고 있다.

임플란트의 재료 기술뿐 아니라 임플란트의 시술 과정도 치 과 디지털화로 인해 비약한 발전을 이루고 있음에도 불구하 고, 임플란트 수술의 핵심과정이 아닌 시술 과정의 부주의로 인
한 사고는 여전히 발생하고, 환자뿐만 아니라 치과의사에게 엄 청난 고통과 법률적 책임까지 부담하게 하는 결과를 야기한다. 이 중 빈번히 일어나고 있는 문제가 임플란트 구성요소 및 시술 기구 즉, 커버 스크류(cover screw)나 각종 어버트먼트(abutment), 헥사드라이버(Hexa driver) 등과 같은 소기구들이 환자 구강 내에 떨어져 삼키게 되는 경우이다.

치과진료 중 이물질 흡입에 관한 사례는 모든 연령대에서 오 랫동안 다양하게 보고되어 왔다[1-3].

골드인레이나 크라운, 근관치료용 파일, 클램프, 스켈러 팁,

Received January 22, 2019; Revised February 28, 2019; Accepted March 7, 2019

Corresponding author: Mee-Kyoung Son, Department of Prosthodontics, School of Dentistry, Chosun University, 309 Pilmun-daero, Dong-gu, Gwangju 61452, Korea.

Tel: +82-62-220-3820, Fax: +82-62-227-7811, E-mail: son0513@chosun.ac.kr 
파절된 기구, 그리고 임플란트 치료에 사용되는 커버 스크류, 인상용 코핑, 임플란트 지대주, 힐링어버트먼트(healing abutment), 헥사드라이버뿐만 아니라 임시틀니나 국소의치와 같은 부피가 큰 물질을 삼키는 경우도 있다.

Fig. 1은 파킨슨 질환을 갖고 있는 환자가 임플란트 치료 중 스크류드라이버를 삼켜 환자의 폐 내로 삽입된 사고를 보여주 는 흥부 방사선 사진이다. 노인 환자의 경우 특히, 연하에 관여 하는 근력 감소 및 구토반사의 감소와 인지장애, 파킨슨병과 같 은 고령화에 따른 일반적인 질환 및 전신건강 상태 등은 삼킴 장 애의 위험성을 증가시킬 수 있어 치과시술 도중 재료 및 기구를 삼킬 가능성이 매우 높다. 최근 65세 이상 환자의 임플란트 보 험혜택으로 노령인구의 임플란트 시술이 갈수록 증가하고 있는 상황에서 이와 유사한 사고의 가능성이 지속적으로 증가하고 있다.

이물질이 기도로 들어가는 경우, 비가역성 폐 손상(irreversible lung injury)을 야기할 수 있고 환자가 생명을 잃을 수도 있 는 매우 심각한 상황에 처할 수 있다.

치과 치료과정 중 삼킴 사고에 대해서 발표한 논문들이 있다. Grossman [4]에 의하면 근관치료 과정에서 근관치료용 파일이 나 리머(reamer) 등을 삼키는 빈도가 높다고 보고하였고 이러한 사고의 $87 \%$ 가 식도를 통해 삼켜지거나 $13 \%$ 는 기도를 통해 흡 인되었다고 하였다. Dichter [5]는 삼켜진 이물질의 $80 \%$ 는 식도 로, $20 \%$ 는 기도로 흡입되었다고 보고한 바 있다.

기도가 아닌 식도를 통해 위장관으로 향하게 되는 경우에도 작고 매끄러운 이물질은 위험성이 덜하지만 임시틀니의 클라스 프(clasp)와 같이 날카롭고 뽀족한 고리 등이 있으면 내시경을 통해 빼내거나 장을 통해 배출될 수 있어 내부기관에 상처를 주 거나 출혈을 야기해 더 큰 문제를 야기하기도 한다.

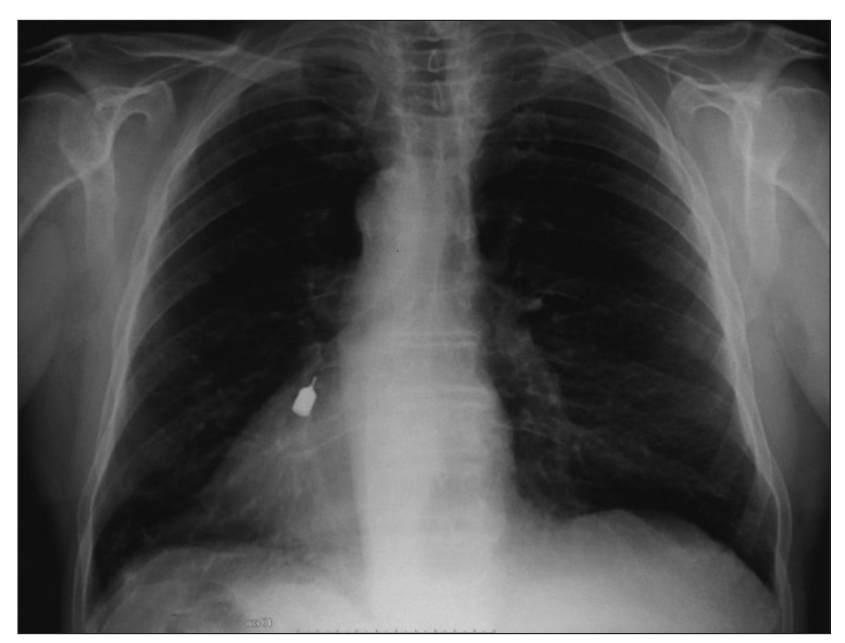

Fig. 1. Chest X-ray showing the aspiration of Hexa driver.
이물질이 기도로 들어가는 경우는 말할 것도 없지만 식도로 들어갔다는 확신이 있다 할지라도 의과적 의뢰와 방사선 촬영 등 필수적인 진단이 빠르게 이루어져야 하고 응급처치 등의 치 료가 이어지도록 의료진이 최선의 의무를 다하고, 또 사고가 완 전하게 종료될 때까지 주의 깊은 모니터링을 하는 것이 추후 발 생할 환자와의 관계 또는 법률적 책임에 대처하는 필수적인 과 정이 된다[5].

치료과정 중 이물질 삼킴에 대한 다양한 원인들이 제시되었 다. 시술 과정 중 글러브를 끼고 소기구를 잡게 되는 손가락 부 분이 타액 등으로 미끄러운 경우, 치료 부위의 시야확보가 어렵 고 접근이 어려운 경우, 환자의 구강이 좁고 짧은 구개를 가진 경우, 거대설과 같은 환자의 해부학적 요인으로 이물질의 삼킴 이나 흡인 사고의 위험이 높다[6]. 치과 치료 시 환자의 예상치 못한 움직임이나 환자의 위치 즉 자세도 큰 영향을 미치는데 환 자를 supine position으로 유지하는 경우 환자의 머리가 반듯하 게 된 상태로 치료를 하게 되어 구강-인두기관이 일직선이 되므 로 목 안에 이물질이 떨어졌을 때 곧바로 삼킬 가능성이 매우 높 다[6]. Obinata 등[7]은 이러한 이물질의 삼킴과 흡인은 치과의 사의 경력이 짧은 경우, 5년 이하의 임상경력을 가진 치과의사 들에게서 더 빈발한다고 하였다. 하지만 경험이 풍부하고 대처 능력이 훌륭한 치과의사라도 이러한 사고의 위험은 늘 존재하 기 때문에 의료진의 주의와 집중이 필요하다. 또한 진료보조자 의 적절하지 못한 행동이나 suction tip에 의한 방해, 불필요한 기구의 접촉 등도 원인이 될 수 있다. 그 외 여러 가지 다양하고 예측하지 못한 요소가 관여한다고 생각할 수 있다.

그동안 치료과정 중 기구나 이물질 흡입에 대한 다양한 대처 방법이 소개되어 왔다. 일반적으로 러버댐의 사용을 권장하고 있으나, 임플란트 치료과정의 특성상 고전적으로 사용되어온 러버댐 등의 방법이 효과적이지 못하였고, 단순히 $2 \times 2$ 거즈를 구강 안쪽에 위치시켜 screen을 하는 방법도 한계가 있기 때문 에 어떻게 이런 사고를 예방할 것인가에 대해 많은 임상가들이 계속해서 고민하고 있다. 따라서 본 연구에서는 기구 삼킴에 대 한 치과의사들의 경험 여부를 간단한 설문을 통해 알아보고, 임 플란트 치료과정 중 필수적으로 사용할 수밖에 없는 소기구 중 특히 힐링어버트먼트나 헥사드라이버 등이 friction의 결여 또 는 술자의 부주의로 인해 구강 내에 떨어지는 사고를 방지하기 위한 해결책을 정리해보고 그 개선방향 및 예방에 관해서 논의 하고자 한다. 


\section{대상 및 방법}

\section{환자 삼킴에 대한 치과의사 경험 유무 설문조사}

치과 임플란트 치료 중 외과적 또는 보철과정에서 필수적으 로 사용하게 되는 헥사드라이버나 각종 힐링어버트먼트 등을 환자가 삼킬 수 있는 위험은 늘 존재한다. 이러한 위험을 실제 임상에서 환자를 치료하는 치과의사들이 얼마나 경험하고 있는 가를 알아보기 위해 설문조사를 실시하였다. 대상은 임플란트 치료를 하고 있는 치과의사 500명이었으며, 참여자들의 개원 여부, 근무지역 및 성별, 연령대는 Table 1과 같다.

Table 1. Survey participants $(n=500)$

\begin{tabular}{lr}
\hline Participant (dentist) & Value \\
\hline Clinic owner & \\
Yes & $419(83.3)$ \\
No & $81(16.2)$ \\
Working region & $264(52.8)$ \\
Metropolitan city & $113(22.6)$ \\
Satellite city & $99(19.8)$ \\
Regional city & $24(4.8)$ \\
Rural area & \\
Sex & $399(79.8)$ \\
Male & $101(20.2)$ \\
Female & \\
Age (y) & $15(3.0)$ \\
$<30$ & $195(39.0)$ \\
$31-40$ & $205(41.0)$ \\
$41-50$ & $73(14.6)$ \\
$51-60$ & $12(2.4)$ \\
$>61$ &
\end{tabular}

Values are presented as number (\%).

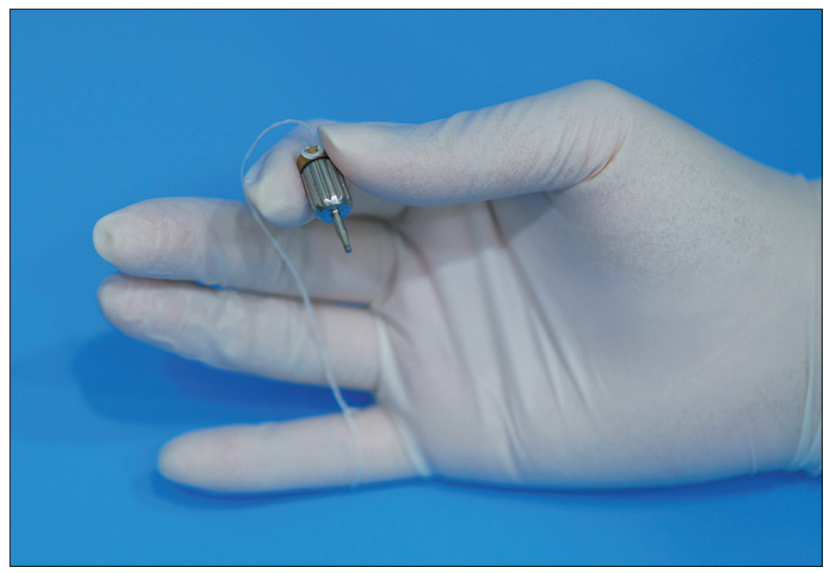

Fig. 2. Using floss tied to a finger.

\section{삼킴 장애 예방을 위한 기존 방법들에 대한 연구}

기구 삼킴 사고를 예방할 수 있는 가장 중요한 것은 치과의사 와 스태프의 위험에 대한 인식과 주의 집중이다. 그리고 환자에 게 미리 고지하고 발생 가능한 상황을 이해시키는 것 또한 매우 중요하다. 환자의 머리가 일직선이 되지 않도록 오른쪽 또는 왼 쪽으로 위치시켜주는 것이나 환자의 상체가 $20^{\circ}-30^{\circ}$ 정도 세워 지는 reverse Trendelenburg position이 환자가 이물질을 삼키 는 가능성을 줄일 수 있다고 한다[6]. 혹시 입안에 이물질이 떨 어지면 삼키지 않도록 환자에게 알려주는 것만으로도 위험가능 성을 상당히 줄일 수 있다.

헥사드라이버가 구강 내에 떨어지지 않게 하려면 방법은 아 주 단순해 보인다. 누구나 다 알고 있는 floss를 묶어서 사용하면 된다. 거의 $80 \%$ 의 응답자가 위험한 경험을 했다는 설문결과를 고려한다면 번거롭고 귀찮다는 이유는 심각하게 생각해봐야 할 사항으로 여겨진다. Floss에 헥사드라이버를 묶어 사용하는 것 이 매우 유용한 방법이지만 실제로 번거롭게 여겨지기 때문에 이 문제를 해결하기 위한 다른 방법들도 소개되어 왔다.

우선 대부분 floss를 묶어 Fig. 2 와 같이 손가락에 감아 사용하 지만 이것이 불편하다면 Fig. 3과 같이 치과의사의 손가락에 반 지를 끼워 여기에 floss를 묶어 사용할 수도 있다.

또 Fig. 4와 같이 floss를 구멍포나 구강 밖의 환자의 옷이나 단추 혹은 floss를 길게 늘어뜨려 놓는 것만으로도 만약의 사태 에 충분히 대비할 수 있다. Floss를 활용할 수 있는 다른 방법은 Fig. 5 와 같이 헥사드라이버에 묶어놓은 floss의 끝부분을 환자 의 반대편 악궁의 치아 인접면 사이에 끼워 걸어놓거나 묶어놓 는 것이다. 이 방법은 손가락으로 floss를 쥐고 있어야 하는 불편 을 해결할 수 있다. Floss를 묶어 사용하는 것이 아무리 불편하

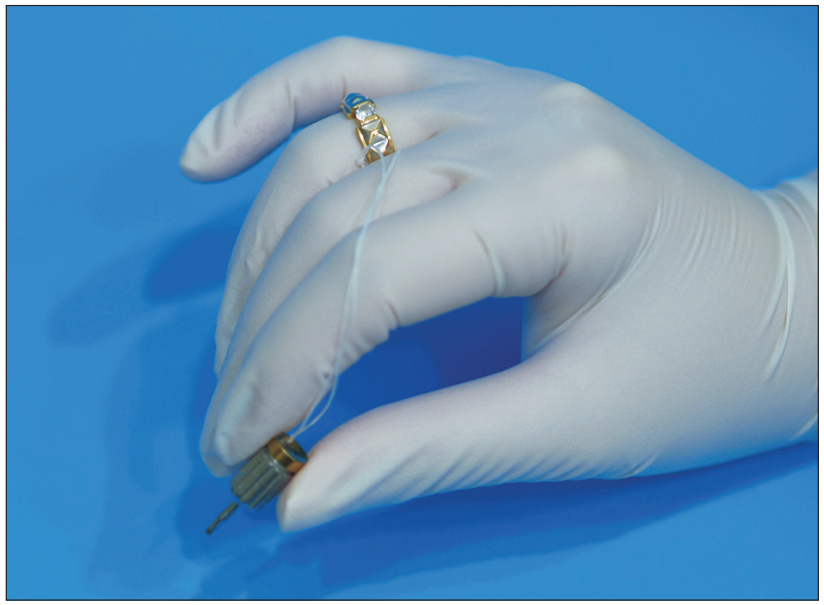

Fig. 3. Using floss tied to a ring. 


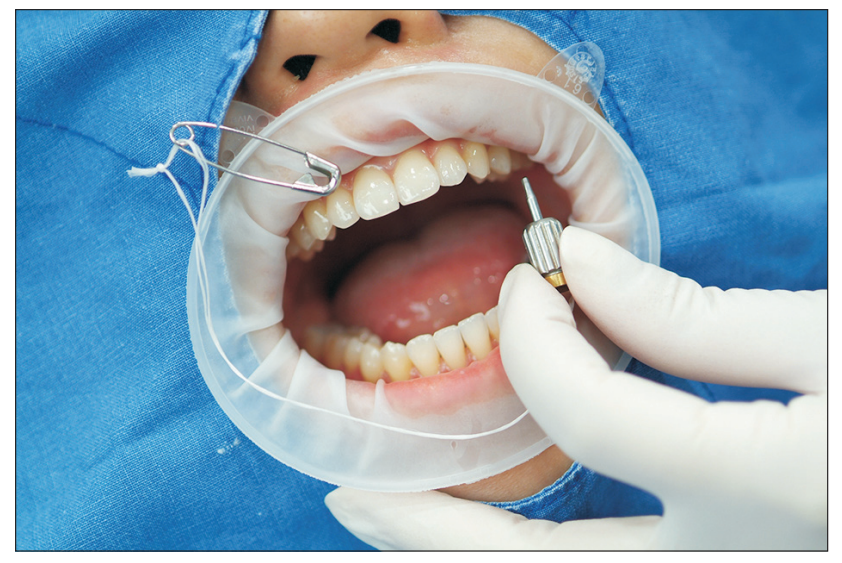

Fig. 4. The floss pinned to the green linen.

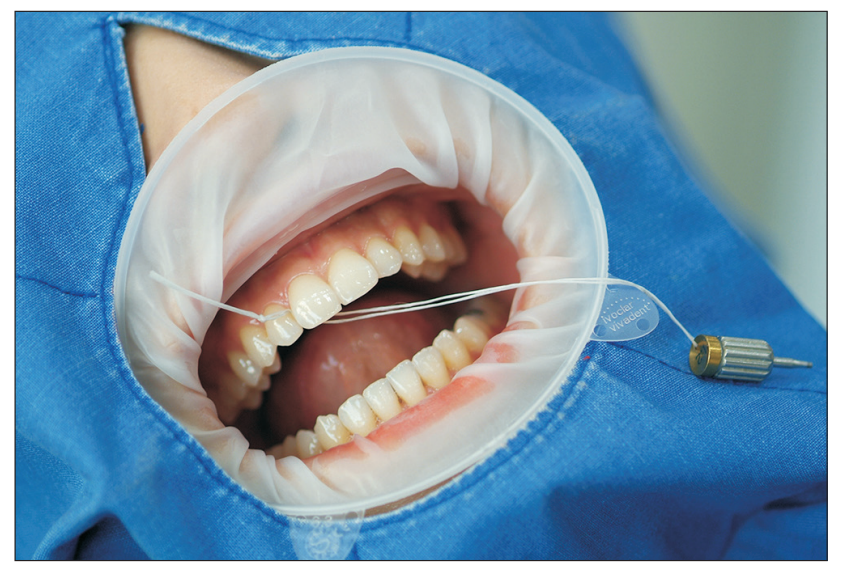

Fig. 5. The floss secured under a tooth contact point.

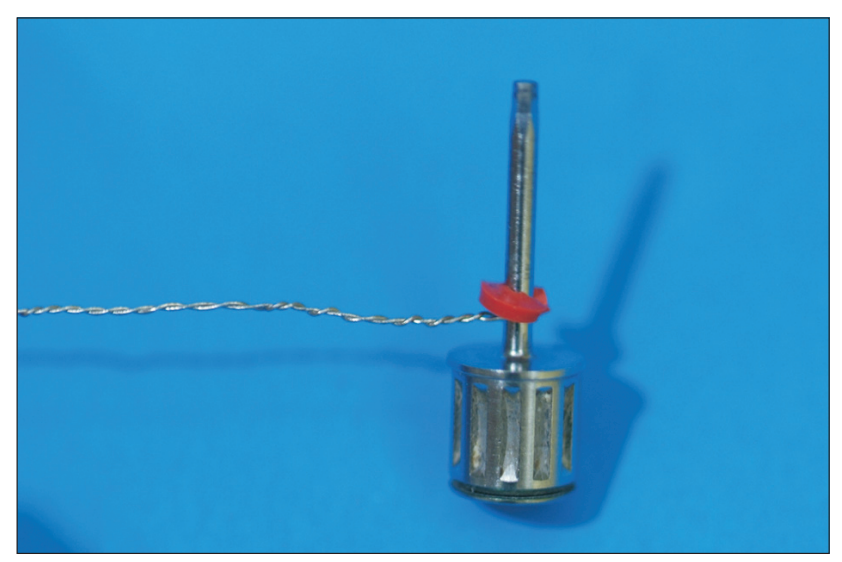

Fig. 6. Hexa driver connected to Orthodontic ligature wire by a rubber stopper.

고 귀찮다 하더라도 그것이 주는 유익에 비한다면 비교할 수 없 는 가치가 있음에 분명하다.

Floss 대신 교정용 ligature wire를 사용할 수도 있다. Fig. 6

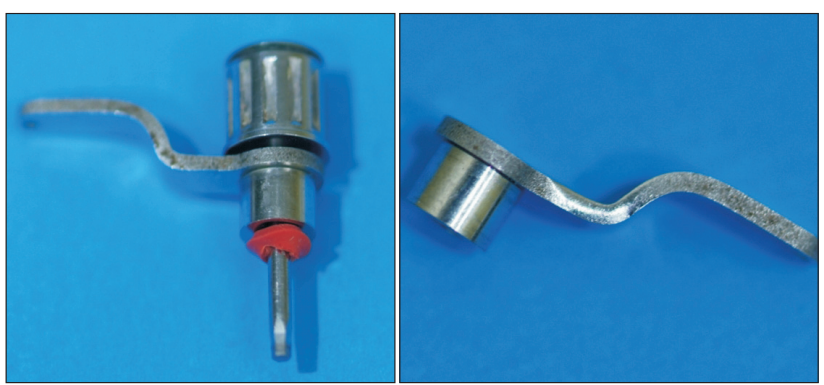

Fig. 7. Hexa driver connected to drill tube by a rubber stopper and 2.0 mm drill tube.

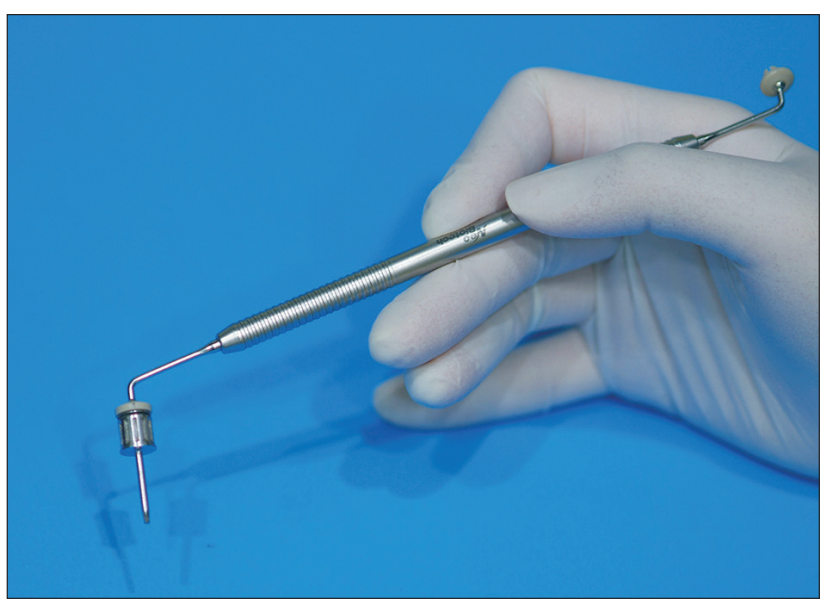

Fig. 8. Neo Company's extended handle for securing the Hexa driver.

과 같이 헥사드라이버 post 부분에 와이어를 연결해 체결하고 하방에 rubber stop이나 O-ring을 끼워놓으면 사용할 때 빠지 지 않고 사용이 가능하며 floss보다는 rigidity를 좀 더 유지하므 로 편리할 수 있다.

또 다른 방법으로는 헥사드라이버의 핸들을 직접 만들어 사 용할 수 있는데 Fig. 7과 같이 가이드를 이용한 임플란트 수술 시 사용하는 $2.0 \mathrm{~mm}$ drill용 튜브를 이용한다. 이 튜브는 손잡이 가 짧은 것도 있고 긴 것도 있는데 손잡이로 사용하기 위해서는 긴 것이 더 유리하다. 시판되는 대부분의 헥사드라이버의 post 직경이 $2 \mathrm{~mm}$ 미만이므로 사용이 가능하고 튜브에 끼웠을 때 빠 지는 문제는 하방에 O-ring이나 근관치료 시 사용하는 파일의 rubber stop을 끼워두면 그 길이를 조절할 수도 있고 빠지지 않 아 안전하게 사용할 수 있다.

시판되고 있는 제품으로는 Fig. 8과 같은 Hexa driver handle (Neobiotech, Seoul, Korea)이 편리하다. 손잡이가 길어 특히 상악 구치부와 같이 접근이 어려운 곳에 사용할 때 용이하다. 상 부의 헤드 부위에 헥사드라이버를 끼울 때 고무탄성을 이용하 므로 매우 안전하고 편리하게 사용할 수 있다.

최근에는 손잡이가 달린 수동기어를 이용하거나 핸드피스를 
이용해 전동으로 헥사드라이버나 커버 스크류를 착탈하기도 한 다. 그렇지만 이러한 장비들 역시 헥사드라이버가 힐링어버트 먼트를 체결하기도 해야 하지만, 곧바로 쉽게 빼내야 한다는 두 가지 기능을 충분히 만족시키기는 어렵기 때문에 여전히 치과 의사의 집중과 주의가 필요하다.

임플란트 치료는 치료과정이 다른 치과치료와는 환경이 다르 기 때문에 러버댐을 사용하는 것이 어려울 수도 있으나 소기구 를 삼키는 것을 예방하는 차원이라면 상황에 따라 사용하는 것 도 가능하다[8]. 그러나 최후방구치부 같은 경우와 같이 구강 상 황에 따라 사용이 불가능할 수도 있다.

또 단순히 $2 \times 2$ 거즈를 구강 안쪽에 위치시켜 screen을 하는 것도 잘 알려진 효과적인 방법이다[9-12]. 그 외 lip retractor (개구기)를 변형시켜 구강의 뒷부분에 강력한 자석을 부착한 stopper를 형성해 혹시 구강 내에 소기구가 떨어지면 자석에 달 라붙을 수 있는 아이디어가 소개되기도 했다[13]. 그러나 어느 정도 효과가 있을지는 의문이며 힐링어버트먼트와 같은 티타 늄 재질로 된 소기구는 자석에 잘 달라붙지 않는다는 사실도 염 두에 두어야 한다. 또 구강 내에 고정된 그물망을 만들어 환자가 삼키는 것을 막아주는 아이디어도 소개되었다.

힐링어버트먼트 상부에 floss를 끼울 수 있는 홀을 만들어 놓 은 아이디어도 있다. 이 홀에 floss를 끼워두면 힐링어버트먼트 가 착탈과정 중 떨어지더라도 안전하다. 다만 이러한 디자인의 힐링어버트먼트를 체결할 때는 구강 밖에서 floss를 묶기 때문 에 번거롭지 않겠지만, 구강 내에 체결된 힐링어버트먼트를 빼 내는 과정에서는 빼내기 전에 구강 내에서 floss를 구멍에 끼워 야 하는 점이 어렵게 느껴진다. 특히 구멍의 방향에 따라서는 봉 합용 needle을 사용한다 하더라도 어려움이 있을 수 있다.

\section{결 과}

\section{설문조사 결과}

본 논문과 관련된 설문 문항은 총 4 개로, 질문과 설문결과는 다음과 같다.

'임플란트 시술 과정 중 헥사드라이버나 힐링어버트먼트가 손가락에서 미끄러져 환자가 삼키지는 않았지만 위험했던 경험 이 있으신가요?'라는 질문에는 ‘예’ 라는 답변이 79.0\% (395명), ‘아니요’라는 답변이 $21.0 \%$ (105명)였다. '임플란트 시술 과정 중 헥사드라이버나 힐링어버트먼트가 환자 구강 내에 떨어져서 환자가 삼킨 경험이 있으신가요?'에 대한 질문에는 80.8\% (404 명)가 '없음', '환자가 식도로 삼킨 경험이 있다'가 $17.4 \%$ (87 명), ‘환자가 기도로 삼킨 경험이 있다’가 $1.8 \%$ (9명)로 나타났 다. 총 설문 대상자 중 103 명 (20.6\%)만이 '헥사드리아버에 치
실을 묶어서 사용하고 있다'라고 답변하였다. 치실을 묶어서 사 용하지 않는 이유에 대해서는 '번거롭고 귀찮아서' (54.9\%), '다 른 방법을 사용하기 때문에’ (35.3\%), ‘별로 위험하다고 생각하 지 않아서' $(9.8 \%)$ 의 순으로 나타났다.

본 설문을 분석해보면 임플란트 시술 과정 중 소기구를 떨어 뜨려 환자가 삼키지는 않았지만 환자가 삼킬 수도 있었던 위험 을 경험한 응답자가 무려 79\%에 달하고 소기구를 환자가 삼킨 경험이 있는 경우도 $19.2 \%$ 로 응답자 5 명 중 거의 1 명에 해당하 는 결과를 보여주었다. 이러한 높은 위험에도 불구하고 특히 헥 사드라이버를 구강 내에 떨어뜨리지 않는 가장 효과적인 방법 중의 하나로 알려진 floss에 묶어 사용하는 응답자는 $20.6 \%$ 에 불 과했고 또 사용하지 않는 응답자의 $54.9 \%$ 가 번거롭고 귀찮아서 를 그 이유로 들었다. 여기서 주목해야 할 문항은 환자가 소기구 를 삼키지는 않았지만 삼킬 수도 있었던 위험을 경험했던 응답 자가 $79 \%$ 에 달한다는 것이다. 이 경우 예기치 않은 사고가 발생 하지 않은 것은 환자나 치과의사에게 매우 다행스러운 일이지만 그저 운이 좋았다는 확률적 의미로만 설명할 수 있기 때문에 실 제 환자가 삼킨 경우를 포함해 분석해본다면 매우 많은 치과의 사들이 이러한 위험에 노출되고 있다는 사실을 추측할 수 있다.

\section{새로운 해결방법}

최근에 소개된 새로운 디자인의 힐링어버트먼트는 이러한 문 제를 상당히 해결할 수 있을 것으로 기대된다. 이 아이디어는 기 존의 헥사드라이버와 힐링어버트먼트가 헥사구조의 friction에 서 유지력(retention)을 얻는 것에 비해 이중 나사선을 이용해서 드라이버와 어버트먼트가 분리되는 것을 방지한다. 기존의 제 품들은 헥사드라이버로 힐링어버트먼트를 체결할 수 있어야 하 지만 체결 직후 곧바로 쉽게 빼낼 수 있어야 하기 때문에 착탈의 두 가지 상황에서 항상 떨어질 수 있는 위험을 갖고 있었다.

Fig. 9와 같이 이 힐링어버트먼트는 내부에 2층으로 서로 굵 기가 다른 나사선을 가지고 있고 이 나사선과 체결되는 2 개의 나사를 양쪽에 가진 드라이버로 구성되어 있다. 먼저 힐링을 체 결할 때는 오른나사와 오른나사선을 이용하게 되고 힐링을 제 거할 때는 왼나사와 왼나사선을 이용하게 된다. 힐링어버트먼 트를 드라이버를 이용해 착탈할 때 나사가 나사선을 완전히 물 게 되므로 구강 내에 떨어질 위험성을 현저히 줄일 수 있게 된 다. 즉 힐링어버트먼트를 체결할 때는 오른나사를 이용해 체결 하고 힐링어버트먼트를 풀 때는 왼나사를 이용해 풀게 되며 나 사가 나사선에 물려서 고정된 채로 작용하기 때문에 구강 내에 떨어지지 않게 된다. 만약 술자가 핸들에 floss를 묶어 사용한다 면 핸들과 힐링어버트먼트가 서로 결합되어 한 덩어리가 되어 구강 내에 떨어져 환자가 삼키는 사고를 매우 효과적으로 예방 

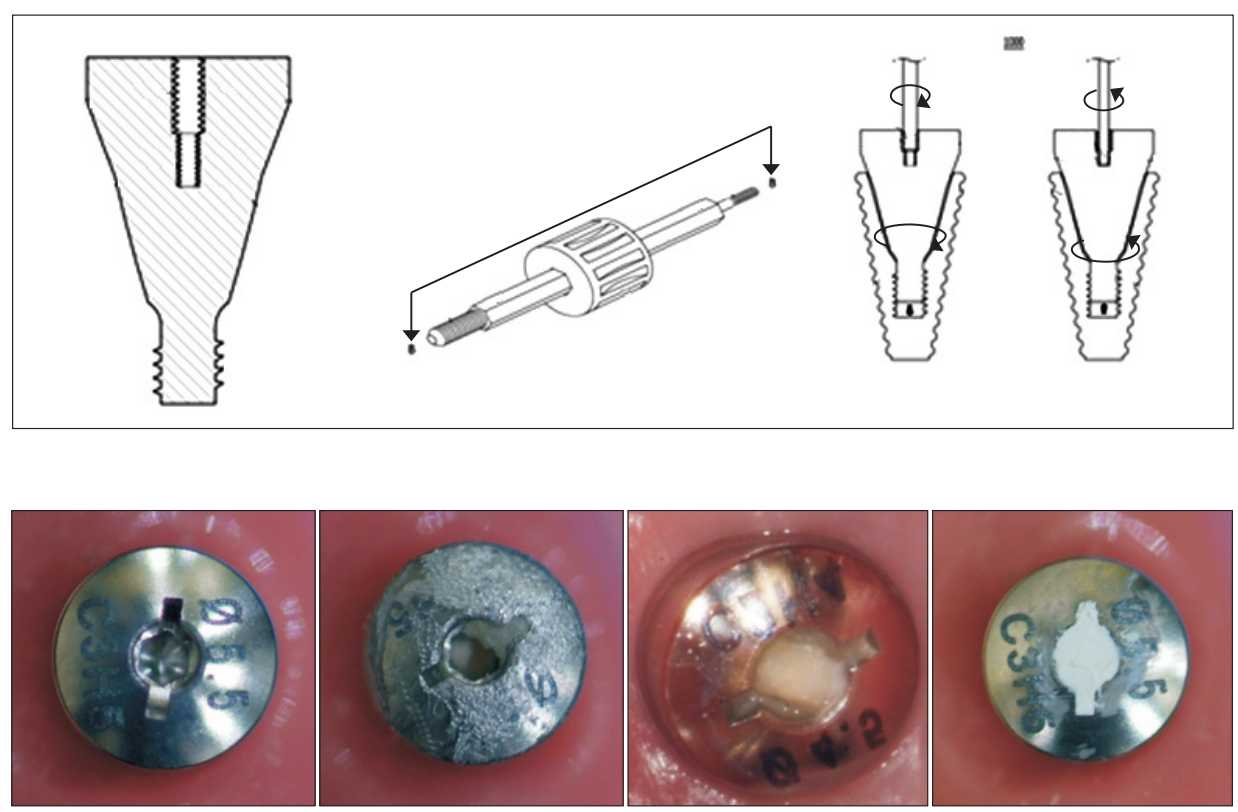

Fig. 9. Healing abutment utilizing Duplex screw system.

Fig. 10. Brand new, contaminated, and filled with temporary stopping material healing abutment.
할 수 있게 된다.

또 다른 효과적 방법으로는 힐링어버트먼트 자체를 자성을 띄는 물질로 만들거나 혹은 힐링어버트먼트 내부에 자석을 삽 입해 자석 또는 자력을 갖는 드라이버 post와 달라붙게 하는 방 법도 고려될 수 있는데 최근 네오디움 $(\mathrm{Nd})$ 자석의 경우 자력이 매우 높기 때문에 가능할 것으로 예상된다.

추가적으로 임플란트 보철과정 중에 이런 위험에 빈번히 노 출되는 예로, 커스텀어버트먼트(custom abutment)와 스톡어 버트먼트(stock abutment)의 경우를 살펴볼 수 있다. 커스텀어 버트먼트는 보통 레진을 이용한 지그를 함께 사용하므로 위험 성을 낮출 수 있지만 스톡어버트먼트는 시판되거나 지그를 만 들어 사용하는 경우가 거의 없기 때문에 스톡어버트먼트용 지 그를 따로 만들어 사용하면 특히 최후방구치쪽에 사용하는 경 우에 있어 구강 내로 어버트먼트가 떨어지는 위험을 줄일 수 있 을 것으로 생각한다.

\section{고 찰}

본 논문에서 소개한 현재까지 개발된 다양한 제품들과 아이 디어들은 몇 가지 단점과 한계에도 불구하고 임플란트 시술 시 소기구들을 환자가 삼키는 사고를 예방하는 데 매우 효과적이 다. 그러나 이러한 사고 예방에 있어 가장 중요한 것은 치과의사 와 스태프들이 잠재된 사고의 위험성을 인지하고 임플란트 치 료의 각 과정마다 주의와 집중을 요하는 것이며 환자에게 적절 한 정보를 미리 제공하는 것이다. 이와 같은 논의들을 정리해보 면 다음과 같다.
1) 술자와 직원들이 소기구를 삼킬 수 있는 위험성을 충분히 인지하고 집중과 주의를 다한다[14].

2) 환자에게 치료 중 가능한 상황을 고지하고 상황에 따른 대 처요령을 알려준다.

3) 위험이 예상되는 경우 chair position을 supine position 보다는 upright로 유지시켜 만일에 떨어졌을 때 목구멍보다는 구강저로 떨어지게 한다.

4) 헥사드라이버는 항상 dental floss나 suture material 등을 이용해 묶어서 사용한다.

5) 힐링어버트먼트는 항상 새것을 사용한다.

6) 힐링어버트먼트 제거 시 헥사홀을 사용 전 깨끗하게 cleaning한다.

7) 좀 더 안전하게 개발된 새로운 시스템을 활용한다.

힐링어버트먼트와 관계된 고찰 시 몇 가지 고려사항이 있다. 현재 시판되는 대부분의 제품의 경우 힐링어버트먼트는 헥사드 라이버와의 friction에 의해 연결된다. 이러한 시스템이 사용된 이유는 헥사드라이버에 힐링어버트먼트를 끼워 임플란트 fixture에 연결할 때 friction에 의해 떨어지지 않게 체결도 해야 하 지만 체결 후 바로 쉽게 빼내야 하는 두 가지 기능을 모두 만족 시켜야만 하기 때문인 것으로 생각한다.

힐링어버트먼트를 체결할 때보다는 빼낼 때 좀 더 위험한 상 황이 발생하곤 하는데 체결 시에는 힐링어버트먼트의 헥사홀이 깨끗한 상태이기 때문에 헥사드라이버와의 유지력이 충분한 반 면 짧게는 며칠 길게는 몇 달까지 구강 내에 머물다 빼내는 경우 힐링어버트먼트의 헥사홀이 음식물 등에 의해 오염되고 이로 인한 유지력이 많이 떨어져 헥사드라이버와의 체결을 방해하기 
때문이다. Fig. 10에서는 구강 내에 체결되기 전의 새 힐링어버 트먼트와 체결된 후 오염된 힐링어버트먼트 그리고 오염을 방 지하기 위해 임시 충전재로 메꾸어 놓은 모습을 보여준다.

따라서 힐링어버트먼트를 풀 때 헤드부분에 있는 헥사홀을 깨끗하게 청소해서 음식물찌꺼기 등 플라그를 제거하는 것이 다. 먼저 탐침 등으로 제거 후 미니브러쉬 등을 이용해서 청소할 수 있다. 그러나 이러한 브러쉬 등을 이용해서 헥사홀을 청소하 는 것도 임플란트 식립위치나 상황에 따라 쉽지 않은 과정이기 때문에 힐링어버트먼트 체결 직후 헥사홀을 임시충전재료 등으 로 메꾸어 놓는 순서를 추천한다.

또 한가지 고려해야 할 사항은 헥사드라이버의 각 임플란트 회사별 호환성에 관한 문제이다. 대부분의 헥사드라이버들이 오차범위 내에서 호환 가능하나 몇몇 제품 등은 오차가 존재하 므로 각 회사별 힐링어버트먼트와 헥사드라이버의 사용을 확인 해야 하며 오랜 시간 헥사드라이버를 사용할 때 post tip의 헥사 부분이 마모될 가능성이 높기 때문에 주기적으로 확인하고 교 체하는 것 역시 고려해보아야 한다[15].

성공적인 임플란트 치료란 진단에서 출발해 모든 외과적 과 정과 보철과정 그리고 유지관리까지, 계획되었고 예상되었던 기준의 성공을 의미할 수 있다. 그러나 이러한 임플란트 치료과 정 중에 발생할 수 있는 소기구의 삼킴이나 흡인과 같은 사고는 그동안의 모든 치료과정의 수고와 노력을 한 순간에 물거품으 로 만들 수 있을 만큼 심각한 결과를 야기할 수도 있으며 치과 의사에게 법적·의료적 책임을 엄중히 물을 수 있다. 이러한 사 고의 위험성과 중요성을 치과의사와 스태프들이 모두 인식하고 모든 과정마다 최선을 다해야 한다[16]. 임플란트 치료과정 중 삼킴이나 흡인의 가능성이 높은 헥사드라이버나 힐링어버트먼 트는 조금만 더 주의하고 원칙을 지키며 안전을 위해 개발된 시 스템을 활용한다면 충분히 예방할 수 있을 것이다.

\section{ACKNOWLEDGEMENTS}

This study was supported by research fund of Chosun University Dental Hospital 2017.

\section{CONFLICTS OF INTEREST}

The authors declare that they have no competing interests.

\section{ORCID}

Yong-Seo Kim https://orcid.org/0000-0003-1876-1791
Jee-Young Kim

https://orcid.org/0000-0003-4639-1505

Yu-Ri Heo

https://orcid.org/0000-0002-1806-3822

Mee-Kyoung Son

https://orcid.org/0000-0001-9225-1744

\section{REFERENCES}

1. Deliberador TM, Marengo G, Scaratti R, Giovanini AF, Zielak JC, Baratto Filho F. Accidental aspiration in a patient with Parkinson's disease during implant-supported prosthesis construction: a case report. Spec Care Dentist 2011;31:156-161. doi: 10.1111/j.1754-4505.2011.00202.x.

2. Zitzmann NU, Elsasser S, Fried R, Marinello CP. Foreign body ingestion and aspiration. Oral Surg Oral Med Oral Pathol Oral Radiol Endod 1999;88:657-660. doi: 10.1016/ S1079-2104(99)70004-1.

3. Başoglu A, Çelik B, Demircan S, Akdag AO, Gündogdu B, Kaya S, Büyükkarabacak YB, Yetim TD. Foreign body in adult branchial. J Exp Clin Med 2004;21:117-122.

4. Grossman LI. Prevention in endodontic practice. J Am Dent Assoc 1971;82:395-396. doi: 10.14219/jada.archive.1971.0052.

5. Dichter D. Accidental ingestion of dental materials: treatment and prevention [Internet]. Scottsdale: SPEAR; 2015 Oct 29 [cited 2018 Aug 12]. Available from: http://www. speareducation.com/spear-review/2015/10/accidentalingestion-of-dental-materials-treatment-and-prevention.

6. Jeon HS, Lee JH. Prevention and management of foreign body ingestion and aspiration during the dental treatment. J Dent Rehabil Appl Sci 2018;34:63-71. doi: 10.14368/ jdras.2018.34.2.63.

7. Obinata K, Satoh T, Towfik AM, Nakamura M. An investigation of accidental ingestion during dental procedures. J Oral Sci 2011;53:495-500. doi: 10.2334/josnusd.53.495.

8. Tory $\mathrm{S}$. The use of a dental dam during implant placement a novel case report and review. Dent Implants Dentures 2016;1:109. doi: 10.4172/2572-4835.1000109.

9. Pull Ter Gunne L, Wismeijer D. Accidental ingestion of an untethered instrument during implant surgery. Int J Prosthodont 2014;27:277-278. doi: 10.11607/ijp.3546.

10. Tiwana KK, Morton T, Tiwana PS. Aspiration and ingestion in dental practice: a 10-year institutional review. J Am Dent Assoc 2004;135:1287-1291. doi: 10.14219/jada. archive.2004.0404.

11. Mahesh R, Prasad V, Menon PA. A case of accidental aspiration of an endodontic instrument by a child treated under conscious sedation. Eur J Dent 2013;7:225-228. doi: 10.4103/1305-7456.110191.

12. Mohan R, Rao S, Benjamin M, Bhagavan RK. Accidental 
ingestion of a barbed wire broach and its endoscopic retrieval: prevention better than cure. Indian J Dent Res 2011;22:839-842. doi: 10.4103/0970-9290.94681.

13. Ismael G, Alameida LD, Lacerda TSP. Prevention from swallowing or aspiration in dentistry for elderly patients. MOJ Gerontol Ger 2018;3:124-126. doi: 10.15406/mojgg.2018.03.00097.

14. Umesan UK, Ahmad W, Balakrishnan P. Laryngeal impaction of an archwire segment after accidental ingestion dur- ing orthodontic adjustment. Am J Orthod Dentofacial Orthop 2012;142:264-268. doi: 10.1016/j.ajodo.2011.05.025

15. Kim MS, Lee JH. A study on the compatibility of implant drivers. J Korean Acad Prosthodont 2014;52:34-41. doi: 10.4047/jkap.2014.52.1.34.

16. Catalano M. Patient death occurs subsequent to swallowed dental tool [Internet]. Fort Wayne: Medical Protective; 2010 Dec [cited 2018 Aug 12]. Available from: https:// www.medpro.com/malpractice-minute-december-2010. 